\title{
Fostering children's music in the mother tongue in early childhood education: A case study in Zambia
}

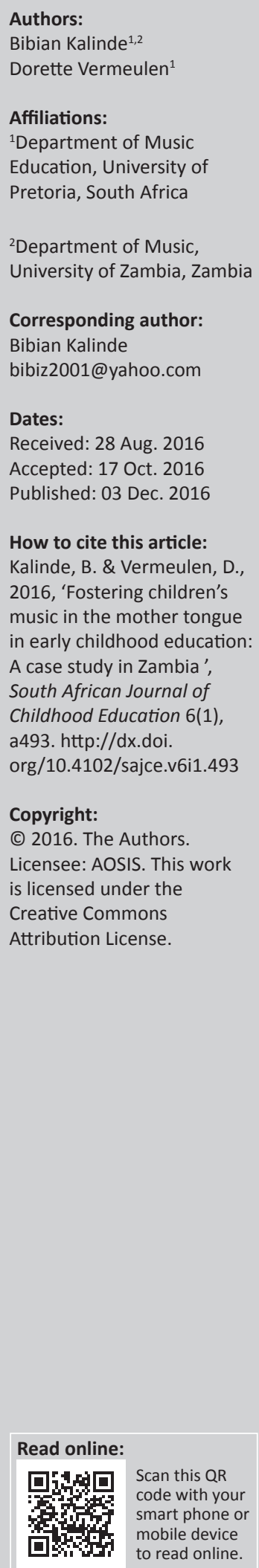

The influence that the use of a familiar language has on learning has long been explored with suggestions that a child's mother tongue is the most suited initial language of instruction in school. In Zambia, however, this is not the case as the majority of people think that young children should learn to speak in English as soon as possible because this is the language of education. As a result, songs in English dominate the singing repertoire in pre-schools even when children have not mastered sufficient English vocabulary. Singing songs in English, just as teaching children in a language they do not understand, has been shown to hamper learning. The theoretical lens of indigenous African education underpins the study in order to investigate how music in the mother tongue in a cultural context can foster educational aims. Research participants included an expert in Zambian indigenous children's songs who also acted as resource person and led 18 children aged between 5 and 6 years in sessions of music in their mother tongue. The findings of the study revealed that educational implications of children's participation in music in the mother tongue can be found in the way in which they are organised, the activities they involve and in the music elements that characterise them.

\section{Introduction}

Learning in a foreign language that children are not conversant with has been argued as contributing to the impediment of learning among African children (Diop 2000:90). Although it is accepted that learning does not always involve language, it is through language that most conceived ideas are indicated and expressed (Bodrova \& Leong 2007:14, 65). When an unknown language is used in instruction, learners struggle to integrate the meaning of new words with what they already know (Diop 2000:90). Benson (2005:2) contends that the use of the mother tongue in education is beneficial for both the teacher and learners in creating a natural means of interaction in which teachers do not have to translate meanings of content while children easily make connections between the symbols and meanings of the content they are learning. Since knowledge is culturally determined, Muchenje and Goronga (2013:890) add that children should be educated in a language that they are conversant in.

The propagation of language and music in the mother tongue in education can be broadly viewed as an effort towards Africanisation (Cabral 1998:263), which is often associated with the propagation of going back to the African way of life, particularly its philosophy, and a revival of traditional African culture (Eze 1998:213; Okonkwo 1998:257). Eze (1998:217), Horsthemke (2004:571) and Muchenje and Goronga (2013:886) argue that this can be achieved through the integration of African ideologies and indigenous knowledge systems (IKS) through practical application in school systems. An education that promotes the use of African tools such as language and music is seen by Africanists as a secure way of regaining what was lost through colonisation (Eze 1998:258; Muchenje \& Goronga 2013:890). Music in the mother tongue can therefore be argued as a means to promote Africanisation when used in education, since it has conveyed and transmitted cultural values in African societies for many generations.

Children's active participation in music activities is a phenomenon found in all cultures of the world. During their lifetime, children acquire music of their own culture through the processes of enculturation and socialisation (Ilari, Chen-Hafteck \& Crawford 2013:204) from family, friends, and the larger community. Added to their early music exposure is the music they find in school and through influences of the media (Campbell 2002:60). The music that children participate in outside of school settings is often in their mother tongue, which is usually the first language that they speak at home or in a locality (Benson 2005). In most African countries, however, the language of instruction in schools is often not the mother tongue. In Zambia, specifically, the medium of instruction has been English for all levels of education until recently when the policy on the use 
of Zambian languages for early childhood education (ECE) and the early grades (1-4) was introduced (Zambia 2012:19).

The argument for the use of music in the mother tongue can be made alongside the general discourse of the use of the mother tongue in schooling. Music and language are cultural phenomena that share a communication role in human life. Just as language is central to human knowledge, meaning and understanding, music in most songs is encoded with particular messages for passing on to others (Nzewi 2003: 13-16). In the study of Venda children songs, Blacking (1967:33) found that texts, phrases or expressions in songs point to culture and thus give insight into a people. Similarities between music and language are also noted in the processes of their acquisition with studies showing music as having a notable impact on language and reading abilities (Hafteck \& Mang 2012:2, 4). Most songs currently used in Zambian preschools are English rhymes/folk songs and Sunday school songs (Kalinde 2016). However, most children do not understand what they sing and usually substitute English words in the songs with similar sounding words in the local languages. In Table 1, some lines of the Zambian national anthem are shown alongside children's version in italics indicating that the original meaning of the text is not conveyed or understood by the children singing the anthem.

In a study by Kennedy and Guerrini (2012:86-87) to determine whether students in a Canadian secondary school could sing their national anthem accurately in relation to the lyrics and melody, it was found that students who are English and French speakers usually substituted the correct words with others and also made errors of pronunciation. It is expected therefore that errors by younger learners would be more pronounced.

Levinowitz (1993:3) is of the view that performing music of one's own culture in a known language is natural to children and that the ability to perform it accurately is developed at an early age. Kodály contends that this is made easy by the natural stress pattern of words found in both the language and songs of a mother tongue (Chen-Hafteck 1997:82). Several other educators have placed music of children's indigenous culture as key in laying a basis for music education. Nketia (1999:19, 23, 35) emphasises an early start to music education that first explores children's immediate music experiences before introducing other music. Njoora (2000:8) adds that songs in children's mother tongue have the potential to augment teaching materials and can be used to teach music notation and composition, as well as to aid children to comprehend music concepts such as rhythm and musical form.

In Africa, music does not exist devoid of other activities; hence it is conceptualised as musical arts that combine music, dance, poetry and costume art (Nzewi 2003:13). Consequently, varied terms are used to describe children's music, such as musical play songs, game songs, musical play (Mans 2002), singing games (Mans 2002; Omolo-Ongati 2005) and game songs (Mtonga 2012). Specifically, among the Tumbuka and Chewa tribes of Zambia, music consists of singing, games, play, and dance and is called Masewera and Zgaro, respectively (Mtonga 2012:15). The aim of this study was to investigate how music in the mother tongue in a cultural context can foster and nurture educational aims. The following questions guided the investigation: How is children's music in the mother tongue organised in a cultural context? What activities comprise children's music in the mother tongue in a cultural context? What are the characteristics of children's music in the mother tongue?

\section{Theoretical framework}

This study conceptualises children's music in the mother tongue in the broader context of African music as a means to education. Indigenous education is a sum total of Africa's culture to which music in the mother tongue forms a greater component (Gwanfogbe 2011:41). Even though African societies vary widely, generalisations on its education system have been argued based on common philosophical and sociological foundations which exist in most African societies (Bray, Clarke \& Stephens 1999:17). This article therefore leans on the indigenous African outlook regarding education, particularly its nature, the way it is acquired and its functions in fostering children's music in the mother tongue in 21st century schooling.

The first characteristic of indigenous African education is that it is functional and aligned to the way of life of its people (Baguma \& Aheisibwe 2011:24; Bray et al. 1999:18; Gwanfogbe 2011:43). From childhood, an individual is prepared for future life roles in view of his or her contribution to the larger society (Funteh 2015:143). Music plays a significant role in the socialisation process of imparting desired values, attitudes and behaviours as children progress through various stages of life (Becker 2012:42). In order for music to play a meaningful function in schooling, Bresler (1998:1) contends that it should be harmonised with the contexts and conditions under which it is generated and experienced. According to Nyota and Mapara (2008:190), this would mean

TABLE 1: Example of children's version of the Zambian national anthem.

\begin{tabular}{|c|c|c|}
\hline Original English text & Children's version & Comments \\
\hline Stand and sing of Zambia & stan an see or Zambia & Stan is a nonsense sound, while sing is replaced by 'see'. \\
\hline $\begin{array}{l}\text { Land of work and } \\
\text { joy in unity }\end{array}$ & $\begin{array}{l}\text { lando fyeka njoy unipy } \\
\text { lando weka njoyi unipy }\end{array}$ & $\begin{array}{l}\text { The word 'work' is replaced with fyeka or weka, both words meaning 'alone' in the Nyanja or Bemba dialects. } \\
\text { The word 'unity' is replaced with unipy which can be closely related to UNIP, a known Zambian political party. } \\
\text { The other words in the song are mere nonsense syllables. }\end{array}$ \\
\hline Free men we stand & three may we star & The words as sung by the children are in English but the meaning of the text is changed. \\
\hline $\begin{array}{l}\text { We've won, } \\
\text { freedom's fight }\end{array}$ & we all free door/don't figh & $\begin{array}{l}\text { A significant change of meaning - where the original states that 'freedom's fight' has already been won, the } \\
\text { children's version supports a non-violent approach. } \\
\text { It is also interesting to note that the word 'door' is added, rising questions of how children would interpret this. }\end{array}$ \\
\hline
\end{tabular}


drawing on music in the mother tongue as a greater part of subject matter in education. The functional orientation of African indigenous education can consequently be viewed in line with music engagement not for its own sake but to serve particular aims in schooling.

A second feature of indigenous African education is that knowledge is transmitted via adults or more experienced persons to the young through apprenticeship using methods of communication that include storytelling, language, dance and music (Omolewa 2007:600). Unlike other instances of learning where the purpose is largely cognitive, apprenticeship enables moral and ethical values to be transmitted in the process (Odora Hoppers 2000:7). Apprenticeship can be interpreted as the principal outlook of African music in which music is taught alongside other aspects of life. Tracey (1980:33) describes it as learning 'a whole approach to life'. As argued by Odora Hoppers (2000:6, 7), learning to be is an overriding constraint in the Western system of education, indicating that there is a need to recover the ethical and humanistic principles so lacking in education thinking today. Bowman (2012:29) expresses a similar thought for music education when he considers individual social and moral transformation that happens as a result of experiences in music. From this perspective, adults involved in sharing music in the mother tongue with children must assume a broader role of imparting knowledge alongside desirable values, skills and attitudes.

Thirdly, the African education philosophy embraces an inclusive approach in the attainment of knowledge (Omolewa 2007:594). Although the uniqueness of the individual is recognised, it is not exalted and separated from the broader communal well-being (Bray et al. 1999:16; Gbadegesin 1998:131). This is emphasised by Barab and Duffy (2012:37) who stated that learning should not only be centred on the individual but that it should stimulate learners to become part of issues that concern the community at large. This view corresponds with the principle of humanism (Okonkwo 1998:258) which, according to Kelly (1999:165) contrasts African education with Western forms of education that promote individualism and see the individual as the originator of knowledge (Scrimsher \& Tudge 2010:296). Tracey (1980:33) contends that participation in African music involves relating with one another as opposed to the sole display of individual skill. The understanding of music in the mother tongue can greatly facilitate understanding of learning as a social and cooperative process in schooling.

Fourthly, being part of a community is fundamental in the way Africans live and learn (Letseka 2000:181). Group-based interactions and interrelations are upheld as a means to learning (Hill 2012:269). Concurring with the African educational philosophy, Dewey believed that children learn best when they interact with other people; working side by side and cooperatively with peers and adults (Mooney 2013:16). This view is supported by Letseka (2000:102-103), namely that children's ability to learn is the result of both intrinsic inspiration and extrinsic input from others.
Stevens and Akrofi (2010:221) regard participation in music in the African way of life as contributing greatly in the propagation of social interdependence. Unlike in the West where music participation is usually restricted to passive listening, African music involves active participation by performers as well as the audience (James 1999). Music in the mother tongue can particularly foster collaborative and active participation in teaching and learning situations.

\section{Research methodology}

In the qualitative approach adopted for this study, the first author acted centrally in the process of observing and understanding the phenomena under study through involvement with research participants (Creswell 2013:4547, 2014:14; Descombe 2010:133; Kumar 2014:14; Schurink \& Fouché 2011). To investigate music in the mother tongue, an ethnographic case study design was employed, focusing on how events happen and what the events meant to those involved (Murray \& Beglar 2009:47). Observation is an overriding method in ethnography. Complete participant observation was particularly adopted to allow for first-hand researcher experiences (Creswell 2013:167). An assistant was engaged to take videos that were later watched for a comprehensive record of notes and to aid in data analysis.

The total study sample included an expert, Mr. Andrew Muwowo, and 18 children from a nursery school aged between 5 and 6 years. The expert - also considered a resource person - was purposively identified to be part of the study based on his many years of music teaching and documented research in folk and children's music from various tribes in Zambia. This study considered ethical issues by ensuring informed consent of all research participants (Kumar 2014:285). Parental consent was obtained for the 18 participating children, and consent was also obtained from Mr. Muwowo to be a resource person. The revelation of identity applied specifically to Mr. Muwowo whose status as an expert in Zambian children's music was considered vital for other researchers to know.

\section{Data collection and analysis}

Mr. Mowowo led the 18 children in music in the mother tongue sessions in a school hall with the first author as complete participant observer (Creswell 2013:166). Mr. Muwowo also represented a grandfather or bashikulu or asekulu, in the Bemba and Nyanja languages, respectively, who tell stories to children in most African contexts (Okafor \& $\mathrm{Ng}^{\prime}$ andu 2005:179). From a wide range of children's music collected and documented by Mr. Muwowo, 16 songs were selected by the first author to represent activities of children's music in the mother tongue in Zambian languages. Each music session lasted between 20 and 25 minutes and started with a story time accompanied by song learning and a demonstration of the accompanying actions or movements.

Interpreting the children's music gathered through observation and participation was weighed against what was 
video-recorded, thus ensuring data validity (Hopkins 2002:135). Other steps undertaken to increase the reliability of the research methodology included lengthy checking and cross-checking of transcribed data and the identified themes to eliminate possible errors (Creswell 2014:203).The process of data analysis began with transcription of raw data collected from observations supplemented by video footage. Underlying explanations from observed data were sought in order to obtain themes and sub-themes (Creswell 2013:186). Thematic analysis is consequently used to present the findings of the study (Creswell 2013:197).

\section{Findings and discussion}

The following is a presentation of findings and discussion of themes and relevant sub-themes that emerged from data analysis.

\section{Organisation of children's music in the mother tongue}

Although the school hall was not a real or exotic location in which music takes place in cultural contexts of childhood, it was adapted for the music in the mother tongue sessions by removing furniture and excluding teacher participation. Each session followed a similar pattern involving first calling children to attention at the start of the sessions in a chant-like speech with dramatised vocalisations, asking them, 'who wants to sing' or 'who wants to hear a story', to which the children answered 'me!'. This was followed by asking the children to form a circle and sit down. This questioning was done repeatedly until all the children were seated. The formation used in most of the 16 music sessions was a circle, except for the songs performed in line formation.

Ailwood (2003:291) highlights the importance of the physical space in which children's activities occur. Since these spaces are almost always subject to adult control, they should be regarded and tailored as an important resource that can facilitate children's engagement in music activities whether in or out of school. It was observed in the study that the circle formation also termed as ring by Marsh and Young (2006:290) or round by Nketia (1974:225) dominated most sessions. This confirms the observation by Bakare and Mans (2003:219) that it is the most preferred formation in most African performances. In the observed music sessions, the circle could have been favoured perhaps for three main reasons: firstly, it defined the boundaries within which the activities occurred, thereby demarcating an imaginary stage of performance. Most songs required children to stand or move along the circle's circumference or to dance in the centre of the circle. The soloist also usually stood in the centre of the circle. Secondly, the circle enhanced active participation as all members could see each other. Thirdly, it made it easy for children to imitate movements or actions demonstrated by the resource person. Kenney (2010:72) refers to the forming of a circle as gathering time which can indicate a coming together on the 'imaginary stage' not just physically but with the required mental readiness. The analysis of data indicates that in order to settle children down faster in the music sessions, the call to attention had to be dramatised.

\section{The multimodal nature of music in the mother tongue}

Sessions of music in the mother tongue were characterised by four main activities: singing, movements or actions, play and storytelling. These activities did not happen in isolation but are discussed individually here in order to elaborate on each in more detail.

\section{Singing}

Singing was prevalent in all music sessions observed in the study. Songs were in nine different Zambian languages and were taught to children by the resource person in a rote style. When teaching the songs, initial emphasis was placed on the children's response part which was started by saying the text of the songs, slowly, chanting them and eventually singing them after the call part by the resource person as the soloist. The following is the analysis of musical elements of songs in the study.

Call and response form: Call and response was a common feature in all songs in the study. The call and response parts were differently treated in the songs as described in the following cases. There were few instances such as in the opening phrase of the song Wankodo wankodola where the response is an exact repetition of the soloist part. In the majority of songs, the soloist phrase is answered by nonsense syllables or phrases such as Oya ye, yoyo, eya eh and other phrases with different texts. The lengths of the solo and response parts also vary. In some songs, the soloist sings most text while the response part is just responded by a sing word. For example, the solo's 12 words in the song Ntole ntole nsuku ya ntende are responded to by a single word pakashongotwela. The soloist's longer phrase is answered by a nonsense syllable such as in the songs Kakasha and Kambushi. In other songs, however, the soloist's one word is responded to with a longer phrase of three or four words such as in the songs Changa, Manguni ayo and Katundulu. Some songs have phrases that are sung by both the soloist and children such as Namsisi Lombe. Parts sang by all often mark a climax when everyone is supposed to dance or perform actions such as hand clapping.

The call and response format of children's songs is general to African music. Kaemmer (1993:103) describes African music as having a cyclic call and response form in which parts are repeatedly sang without a definite end. The various ways in which the solo and response parts alternate as explained above can be said to stress communality rather than individuality in children's music performance (Blackwood, Roberts \& Campbell 2012:47). All the participating members, that is, the soloists and respondents do not dominate but uphold performance as a moment of shared enjoyment. This aspect has significant pedagogical inference in getting all children to actively participate in classroom activities. 
Melodic structures and tonality: Children's songs observed and recorded in music sessions of the study were short and repetitive. This can perhaps explain why children learnt them easily. Tonal combinations in the songs were based on the anhemitonic scale and hemitonic variations of the pentatonic scale. A stepwise motion is noted in most songs with wide leaps being restricted to the soloist parts with few cases of intervals of a fourth or fifth such as in the song Manguni ayo. Each pitch in the songs is set to a single syllable. Repetition characterised most children's songs collected from various parts of the world in a study by Pai (2009:1). In Africa, repetition is a dominant feature of all music (James 1999). In children's songs, specifically, repetition can be argued as a useful technique in maintaining song simplicity; since it is combined with actions and movement, monotony may not be easily felt. As general to most African music, the songs in the study have tones that fit within the pentatonic scales with intervals of seconds and thirds (James 1999:8). The setting of pitch to a single syllable of a text which creates a 'text-music relationship' is also evident in Pai's study of children's songs from all over the world (2009:1). A notable insight in the melodic structures of children's songs is that participation in play songs places considerable emphasis on attentive listening. Out of the 16 songs in the study, only one song involved an exact echo of the solo phrase - Wankodo wankodola - indicating that children did not only rely on the soloist parts to cue them in. Their timely responses are an indication that they internalised both the solo part and the varied responses to the call parts.

Rhythmic structures: Songs in the study were characterised by an emphasis on rhythm and percussive effects supplied by hand clapping, feet stamping and tapping the floor with stones. Although songs used fast and contrasting rhythms, this effect was more tied to the activities in the songs. Other rhythmic and percussive effects of hand clapping, feet stamping and tapping of the floor with stones was done to a recurring beat. The common time signature to which most of the songs were in was duple and quadruple as also found in other studies of children's songs by Merriam (1959:16). Rhythmic flow in the songs was characterised by moments of heightened tempo that marked the song climax. In the songs Kache kache and Ntole ntole nsuku ya ntende, two time signatures are used owing to the change of tempo necessitated by the song's climax.

African music is generally known for elaborate rhythms and children's versions are not an exception as established in the study (Blackwood et al. 2012:47; Merriam 1959:15). Rhythm can however be argued as adding more than just the excitement of motion that it brings to music. Instead, it has a greater and essential significance for engaging children in active learning. When children respond to rhythmic drive and percussive effects through bodily actions and movement, active learning is implied (Philpott 2001:80).

\section{Movement and action}

Most of the children's songs in the study were combined with various movements and actions. In the sessions, relevant song movements and actions were demonstrated after the songs were taught. This seemed to work best and required few attempts for children to synchronise the songs with the associated movement and actions. The common body postures observed in the study included straight but not rigid standing, forward and backward bending, sitting and squatting. Specific fine motor actions observed included hand gestures, clapping, placing a hand on the knee, arms akimbo and hand holding. Gross motor movements and actions included swinging forward and backward, foot stepping and stamping, walking, pulling in a tag of war, actions of mimicry, walking, running, hopping and leaping. Half of the songs in the sessions involved the use of stones. The stones were continuously tapped on the floor to the rhythm of the songs and passed on from one child to another to a beat.

The presence of movements and actions in all the songs of the study confirms the findings of other studies by Abril (2011), Marsh and Young (2006), Campbell (2002) and Nketia (1974) that children's songs are inseparable with movement. In the study, it was observed that children were usually alert to coordinate and effect changes of movement immediately as required by the songs as also confirmed in Nketia's study (1974:211). Abril (2011:94) explains that these apt responses to signals of movement change confirm that movement is not trivial but a form of knowing that is specifically expressed through bodily movement and activity. The combination of song, movements and actions in the study can be advanced as setting the right conditions in which active learning for ECE can thrive.

This use of stones in the songs of the study agrees with the observation by Mans, Dzansi-McPalm and Agak (2003:204), namely that children's 'stone songs' are common in Africa. The use of stones in the songs can be closely associated with the dominance of contrasting rhythm in African music performance (Agawu 2003:55). Since specific children's instruments are rare in Africa (Nketia 1974:85), the use of stones may be said to supply the additional rhythmic emphasis and percussive effect that would otherwise be provided by instruments.

\section{Storytelling}

Storytelling observed in sessions of music in the mother tongue was synchronised with singing, movements and acts of play. It was evident that story time was not new to the children. When Mr. Mowowo gave the opening phrase of the story, 'once upon a time', children gave the response 'time time story time will never end start again'. This was followed by song learning and a demonstration of accompanying movements and actions. The learnt songs were then incorporated at various points of the stories. The stories in music in the mother tongue were however short narrations created spontaneously to fit the song context. For instance, 
a brief story of a goat was told with the song Cicila cicila that involved a goat.

The role of singing in storytelling was for the most part remarkable in each session and appeared in the course of storytelling and briefly at the close of the story. The most outstanding feature of storytelling was perhaps the role it played as a recapitulation in the music sessions and the stating of the moral of the story (Mtonga 2012:134). Okafor and $\mathrm{Ng}^{\prime}$ andu (2005:179) liken storytelling to taking children on an imaginary journey; the closing therefore is like bringing them back to reality. At the close of the story, Mr. Muwowo asked questions regarding the main items of the story such as 'what can you say about the story' and 'what was the lesson of the story?' Since the songs were aligned to the story, he sometimes used sung portions to act as cues when children forgot what was told in the story. The song in the story assumed a call and response form. In view of children's lessons, this can provide a point of exchange between the 'teller and the audience' (Okafor \& Ng'andu 2005:181) in which the adult assesses the level of children's understanding of the subject matter and stresses important issues.

Mtonga (2012:133) states that children prefer narratives with song and Mr. Muwowo's use of techniques such as mimicry, voice changes and facial gestures elicited humour as evidenced by children's laughter (Okafor \& Ng'andu 2005:181). Omolewa (2007:599), Okafor and $\mathrm{Ng}^{\prime}$ andu (2005:179) and Mans (2002:54) have described the didactic role of storytelling as transcending in many African societies. The recommendation for the use of storytelling in educational settings is equally made by Omolewa (2007:599) when he states that 'indigenous stories are a culturally and environmentally rich source for teaching'. When music in the mother tongue is used as content in teaching, storytelling is an opportunity to communicate and emphasise key aspects of the lesson.

\section{Aspects of play in music in the mother tongue}

In the study, music in the mother tongue was characterised by a combination of comical sounds, punning and use of nonsense texts which led to constant laughter among the children. Social play or socio-dramatic play was especially observed as governed by simple rules such as 'not to break the chain' in the song Maceni maceni. Rules of play were considered very important and a child who disrupted the activity by not following the rules was rebuked by others. Imitation was manifested in the music sessions when children took on roles to depict animal movements and behaviour in songs such as Kakasha. Other examples of mimicry were evident in the songs Kache kache with children imitating the movement of a small animal at the phrase Kenda ko; in Tufwante menza as children imitated the behaviour of a hen; in Kakasha where they imitated the movement of a diker; and in Katundulu where they imitated the brisk walk of a bird. Play involving substitute objects or manipulation of materials was observed in the music sessions. For example, in the song
Cicila cicila, a tie was used by the children for a goat's tail. The act of joining hands was used as a trap in the song Kakasha and an actual tree branch was rolled back and forth over the head of children in pairs to signify the breaking and putting together of a stick in the song Amina tonga mindose.

Several features of play evident in the study can be associated with characteristics of play as 'enjoyable, free and spontaneous' (Bodrova \& Leong 2007:130). The acts of play evident in the study are those supported by Harris and Park (1983:16) as characterised by imitation, creative activities; exploration; joking; and make believe. Imitation is also included as a great component in pretend play in studies by Mtonga (2012:59) and Norbeck (1974:2). The implication of the evidence of play in music in the mother tongue can be argued as going beyond the experience of joy and fun. Aronstam and Braund (2015:2) contend that play allows children to be actively involved in the acquisition of knowledge. Specifically, play with substitute objects is supported by literature as enabling 'decontextualisation of meaning' which is fundamental in cognitive development (Duncan \& Tarulli 2003:274). Decontextualisation of meaning involves children attaining a mental state that allows them to separate between what is abstract from the physical reality. One example for this, for instance, was where children substituted a real goat's tail with a rag or tie and wagged it as if it was a real goat's tail in the song Cicila cicila.

When children freely submit to the rules ascribed in activities of music in the mother tongue, Ailwood (2003:286) describes it as 'governmentality'. It is an inherent characteristic of play that ensures that children abide by desired standards in order to achieve the desired outcome of their play engagement. Aronstam and Braund (2015:2) distinguish play as formal/ structured and informal. Play in the study happened in what may be regarded as an informal setting. The ways in which it occurred can guide school play that is specifically structured for learning. In adult-led play, Ailwood (2003:293) maintains that 'social and power relations' are evident. Therefore, teacher awareness of their role as 'play facilitators' in children's play can help achieve both recreational and educational outcomes of play.

The presence of mimicry in children's songs is not only characteristic of them having play as an important ingredient in their activities (Mtonga 2012:59; Norbeck 1974:2) but also can point to a relationship with the natural environment. The constant reference to common animals and birds could be that themes and texts in songs relate to what children see in their immediate environments. In the study, play also largely contributed to intensified participation in music through social play that called for teamwork as opposed to individual effort. An example can be seen in the song Namsisi lombe when two opposing sides end up in collaborative play of a tug of war in which the weaker side is pulled over by the stronger one.

Other pedagogical significances of acts of play in music in the mother tongue can be inferred from what was 
observed as motivated, deliberate and voluntary participation of children in music in the mother tongue. Children displayed sustained attention, adherence to rules and willingness to take up roles. Rogers and Evans (2008:16) discuss these aspects as pointing to enhanced intrinsic motivation vital for learning. To confirm children's intrinsic motivation in music in the mother tongue, ending the sessions was met with resistance as children wanted the music sessions to be continued. This observation makes a vital contribution towards making learning musical and playful in order to keep children motivated in situations of learning.

\section{Language and poetic devices in music in the mother tongue}

From the accounts of participation and analysis of video recordings of music in the mother tongue, it was shown found that most songs in the study had animal and bird themes and vocalisations. There was mention of Mkango [Lion], Kakasha [Duiker], Mpongo [Goat], Nguluwe [Pig], Changa [Bush baby] Kambushi [Goat], Katundulu [Robin] and Kamimbya [Swallow]. The use of onomatopoeia was common in the songs as evident in the vocalisation of animal sounds: the 'mee' sound of a goat in the song Cicila cicila and the tete tete hen sounds in the song Tufwante menza. Nonsense syllables and punning were also very common in the songs. Examples found in the study were: oya ye, yoyo, eya eh and nde nde nde.

Discussion of language and music is often focused on hermeneutics that explain 'meanings, associations and connotations' of words (Agawu 2003:115). This is because music is rooted in language not for its own sake but for communication purposes (Kaemmer 1993:108). Interpreting meaning in children's songs can however be puzzling for the reason that children's songs have many sources. Pai's categorisation of children's songs provides useful enlightenment when he argues that children's songs are those 'sang by child[ren], made up by child[ren] or composed for children to sing' (2009:4). As a result, the meanings that are attached to children's songs are in many cases 'denotative' or 'connotative' (Kaemmer 1993:113). In the initial case, meaning is given by the composer, while in the latter, meaning is given by the one who listens, such as a researcher. In both instances, however, the meaning is just implied since it is not given by the children themselves. In any case, the meaning of children songs from an adult point of view may be porous and elusive.

The analysis of the use of language and poetic devices contribute to the playful nature of children's songs and demonstrates how music elicits excitement, amusement and fun rather than to add meanings to the songs. This view is supported by Mtonga (2012:131), namely that language and poetic devices are characteristic of children's songs and serve to fascinate and intrigue them. Mtonga (2012) equally adds that children do not necessarily pay attention to the meaning in the songs they sing but visibly react happily to what the texts imply. Instead, it is the adults who place meanings to children's music. Since the content of the songs may align to specific topics in a classroom, teachers can plan to use certain songs to facilitate specific desired outcomes of learning.

\section{Implications and conclusion}

The aim of this study was to investigate how music in the mother tongue in a cultural context can foster and nurture educational aims. Except for the emphasis on language, the findings of the study indicate that some pedagogical benefits of music in the mother tongue are those applicable to the purpose of music in general education. It has been found in the literature cited in the study that music, play and other related practical activities of movement and actions happen simultaneously when children engage in music This multimodal nature of children's music in the mother tongue confirms the African understanding of music as an integrated art form combining aspects of music, movement, storytelling and play. Similarly, it agrees with a study by Aronstam and Braund (2015:7) of how children's activities often incorporate play, storytelling, art, movement and music. Van Vreden (2016:1) suggests that the combination of these aspects is the surest means towards achieving integration in teaching and learning, especially in cases where teachers have to cover so much content in a short period of time. From the current study, conclusions can be drawn that the multimodal nature of music in the mother tongue facilitates children's cognitive, social, emotional and physical development in the most natural way, hence supporting the discourse of musical activities as developmentally appropriate practice (DAP) (Ailwood 2003:290). The theoretical underpinning of music in the mother tongue in African education in the study has implications in 21st century music education practice as a means of propagating indigenous African education itself. Therefore, children's participation in music in the mother tongue should not be regarded as events of mere entertainment but as important activities to develop socialisation skills.

This study shed more light on language, specifically the mother tongue, as a crucial aspect in facilitating interaction and communication between the teacher and the learners. This is true in both instances when music is used as a means to learning and also as content for teaching. The setting of the study in an out-of-school environment highlights an important contribution in linking knowledge and practice from in and outside of school practice. In order to achieve the desired outcomes of music in the mother tongue in schools, teacher empowerment in the use of cultural resources is key (Cloete \& Delport 2015:86). Music teachers have continually stated a lack of teaching resources in music classrooms as a challenge in teaching the subject (Kalinde 2013:57; Mubita et al. 2005:170), even when music in the mother tongue is a readily available cultural resource. Benson (2005) argues that the use of such resources is beneficial for both the children and the teacher. The teacher does not have to translate the meaning of the songs since the children's understanding is naturally facilitated by song content that is linked to 
environments and situations that both teachers and children live in.

The goal of 'appreciating Zambia's ethnic cultures, customs and traditions' is resounded in Zambian education policy documents (Zambia 1996:18; 2012:3). Policy makers, parents and teachers need to reflect broadly about how this goal can be met through music in the mother tongue, especially with regard to the current policy on the use of Zambian languages which should include songs of the mother tongue as well (Zambia 2012:19). Since the policy to use local languages is only applicable for children in ECE and the early grades of $1-4$, children still have an opportunity to learn English that is acclaimed as an international lingua franca in their later years of schooling for purposes of international communication (Seidlhofer 2005:339)

\section{Acknowledgements Competing interests}

The authors declare that they have no financial or personal relationships which may have inappropriately influenced them in writing this article.

\section{Authors' contributions}

B.K. and D.V. equally contributed to the research and writing of this article.

\section{References}

Abril, C.R., 2011, 'Music, movement and learning', in R. Colwell \& P.R. Webster (eds.) MENC handbook of research on music learning, vol. 2, pp. 92-129, Oxford MENC handbook of res
University Press, Oxford.

Agawu, K., 2003, Representing African music: Post-colonial notes, queries, positions, Routledge, New York.

Ailwood, J., 2003, 'Governing early childhood education through play', Contemporary Issues in Early Childhood 4(3), 286-299. http://dx.doi.org/10.2304/ciec.2003.4.3.5

Aronstam, S. \& Braund, M., 2015, 'Play in grade R classrooms: Diverse teache perceptions and practices', South African Journal of Childhood Education 5(3), $1-10$.

Baguma, P. \& Aheisibwe, I., 2011, 'Issues in African education', in A.B. Nsamenang \& T.M. Tchombe (eds.), Handbook of African educational theories and practices: $A$ generative teacher education curriculum, pp. 21-34, Human Development Resource Centre, Bameda.

Bakare, O.R. \& Mans, M., 2003, 'Dance philosophies and vocabularies', in A. Herbst (ed.), Emerging solutions for musical arts education in Africa, pp. 215-235, African Minds, Cape Town.

Barab, S. A., \& Duffy, T., 2012, From practice fields to communities of practice. In D. Jonassen \& S. Land (eds.), Theoretical foundations of learning environments, pp. 29-65, Routledge, New York.

Becker, J., 2012, 'Cultural considerations: Beyond sounds themselves', in T.E. Miller \& A. Shahriari (eds.), World music: A global journey, pp. 35-59, Routledge, New York.

Benson, C., 2005, The importance of mother tongue-based schooling for educationa quality: EFA global monitoring report.

Blacking, J., 1967, Venda children's songs: A study in ethnomusicological analysis, Witwatersrand University Press, Johannesburg.

Blackwood, J., Roberts, J.C. \& Campbell, P.S., 2012, 'Seeking African music in a national archive: Smithsonian folkways as source material', General Music Today 26(2) 46-50. http://dx.doi.org/10.1177/1048371312462577

Bodrova, E. \& Leong, D.J., 2007, Tools of the mind, the Vygotskian approach to early childhood development, vol. 2, Prentice Hall, Upper Saddle River, NJ.

Bowman, W., 2012, 'Music's place in education', in G.F. Welch \& G.E. Mcpherson (eds.), The Oxford handbook of music education, vol. 1, pp. 21-39, Oxford University Press, Oxford.

Bray, M., Clarke, P.B. \& Stephens, D., 1999, 'The origins and development of education in Zambia: From pre-colonial time to 1996', in M.J. Kelly (ed.), Indigenous forms of education: The individual and society, pp. 16-22, Image, Lusaka.

Bresler, L., 1998, 'The genre of school music and its shaping by meso, micro and macro contexts', Research Studies in Music Education 11(1), 2-18. http://dx.doi. org/10.1177/1321103X9801100102
Cabral, A., 1998, 'National liberation and culture', in E.C. Eze (ed.), African philosophy: An anthology, pp. 260-266, Blackwell Publishing, Oxford.

Campbell, S.C., 2002, 'The musical cultures of children', in L. Bresler \& M.C. Thompson (eds.), The arts in children's lives: Context, culture and curriculum, pp. 57-69, Kluwer Academic, London.

Chen-Hafteck, L., 1997, 'Music and language development in early childhood: Integrating past research in the two domains', Early Child Development and Care 130(1), 85-97. http://dx.doi.org/10.1080/0300443971300109

Cloete, E. \& Delport, A., 2015, 'Music education in the grade R classroom: How three teachers learned in a participatory action inquiry', South African Journal of Childhood Education 5(1), 85-105.

Creswell, J.W., 2013, Qualitative inquiry and research design: Choosing among five approaches, 3rd edn. Sage, Washington, DC.

Creswell, J.W., 2014, Research design, 4th edn. Sage, Thousand Oaks, CA.

Descombe, M., 2010, Ground rules for social research: Guidelines for good practice, vol. 2, Open University Press, Berkshire.

Diop, B., 2000, 'African education: Mirror of humanity', in P. Higgs, N.C.G. Vakalisa, T.V Mda \& N.T. Assie-Lumumba (eds.), African voices in education, pp. 84-102, Juta, Landsdowne.

Duncan, R.M. \& Tarulli, D., 2003, 'Play as the leading activity of the pre-school period: Insights from Vygotsky, Leont'ev, and Bakhtin', Early Education \& Development 14(3), 271-292. http://dx.doi.org/10.1207/s15566935eed1403_2

Eze, C.E., 1998, 'Modern western philosophy and African colonialism', in E.C. Eze (ed.), African philosophy: An anthology, pp. 213-221, Blackwell Publishing, Oxford.

Funteh, M.B., 2015, 'Dimensioning indigenous African education system: A critical theory divide discourse', International Journal of Humanities and Social Science 5(4), 139-150.

Gbadegesin, S., 1998, 'Yoruba philosophy: Individuality, community and the mora order', in E.C. Eze (ed.), African philosophy: An anthology, pp. 130-141, Blackwell Publishing, Oxford

Gwanfogbe, M.B., 2011, 'Africa's triple education heritage: A historical comparison', in T. Tchombe \& B.A. Nsamenang (eds.), Handbook of African educational theories and practices: A generative teacher education curriculum, pp. 40-54, Human Development Resource Centre, Bameda.

Hafteck, L.C. \& Mang, E., 2012, 'Music and language in early childhood development and learning', in G.F. Welch \& G.E. Mcpherson (eds.), The Oxford handbook of music education, pp. 261-278, Oxford University Press, Oxford.

Harris, J.C. \& Park, R.J., 1983, Play, games and sports in cultural contexts, Human Kinetics, Champaign, IL.

Hill, J.R., 2012, 'Learning communities: Theoretical foundations for making connections', in D. Jonassen \& S. Land (eds.), Theoretical foundations of learning environments, pp. 268-285, Routledge, New York.

Hopkins, D., 2002, A teacher's guide to classroom research, 3rd edn., Open University Press, Philadelphia, PA.

Horsthemke, K., 2004, 'Knowledge, education and the limits of Africanisation', Journa of Philosophy of Education 38(4), 571-587. http://dx.doi.org/10.1111/j.03098249.2004.00405.x

Ilari, B., Chen-Hafteck, L. \& Crawford, L., 2013, 'Singing and cultural understanding: A music education perspective', International Journal of Music Education 31(2), 202-216. http://dx.doi.org/10.1177/0255761413487281

James, C., 1999, 'Melodic and rhythmic aspects of African music', in M. Floyd (ed.), Composing the music of Africa, pp. 7-18, Ashgate, Brookfield, WI.

Kaemmer, J.E., 1993, Music in human life: Anthropological perspectives on music, vol. 1, University of Texas Press, Austin, TX.

Kalinde, B., 2013, The implications of arts integration for music education: In Zambian basic schools and teacher colleges of education, Lambert Academic Publishing, Saarbrücken.

Kalinde, B., 2016, 'Cultural play songs in early childhood education in Zambia: In and outside of classroom practice', Thesis, Music Department, University of Pretoria.

Kelly, M.J., 1999, The origins and development of education in Zambia: From precolonial time to 1996. In M. J. Kelly (ed.), Indigenous forms of education: The individual and society, pp. 16-22, Image, Lusaka.

Kennedy, M.C. \& Guerrini, S.C., 2012, 'Patriotism, nationalism, and national identity in music education: "O Canada", how well do we know thee?' International Journa of Music Education 31(2), 78-90.

Kenney, S., 2010, 'Building bridges from circle time to centre time', paper presented at the International Society for Music Education: 14th Early Childhood Music Seminar, Beijing, China.

Kumar, R., 2014, Research methodology: A step-by-step guide for beginners, 4th edn. Sage, London.

Letseka, M., 2000, 'African philosophy and educational discourse', in P. Higgs, N.C.G. Vakalisa, T.V. Mda \& N.T. Assie-Lumumba (eds.), African voices in education, Juta, Lansdowne.

Levinowitz, L.M., 1993, 'Parent education as a beginning solution to musical childhood at risk', Applications of Research in Music Education 12(1), 9-13. http://dx.doi. org/10.1177/875512339301200102

Mans, M., 2002, 'To pamwe or to play: The role of play in arts education in Africa', International Journal of Music Education 39(1), 50-64. http://dx.doi.org/10. 1177/025576140203900106

Mans, M., Dzansi-McPalm, M. \& Agak, H.O., 2003, 'Musical play in arts pedagogy', in M.N.A. Herbst \& K. Agawu (eds.), Musical arts in Africa: Theory, practice and education, pp. 195-214, Unisa Press, Pretoria. 
Marsh, K. \& Young, S., 2006, 'Musical play', in G.E. Mcpherson (ed.), The child as musician: A handbook of musical development, Oxford University Press, Oxford.

Merriam, A.P., 1959, 'Characteristics of African music', Journal of the International Folk Music Council 11, 13-19. http://dx.doi.org/10.2307/834848

Mooney, C.G., 2013, Theories of childhood: An introduction to Dewey, Montessori, Erikson, Piaget \& Vygotsky, Redleaf Press, St. Paul, MN.

Mtonga, M., 2012, Children's games and play, UNZA Press, Lusaka.

Mubita, B., Nyirenda, J., Nayame, J., Kakanda., M. \& Muyunda, A., 2005, 'Factors affecting music education in Zambian Government Schools and the community', in A. Herbst (ed.), Emerging solutior
54-63, African Minds, Cape Town.

Muchenje, F. \& Goronga, P., 2013, 'Education and the revitalisation of indigenous knowledge systems in Africa: A paradigm shift in curriculum content', International Journal of Social Sciences \& Education 3(4), 886-894.

Murray, N. \& Beglar, D., 2009, Inside track: Writing dissertations and theses, Pearson Education, London.

Njoora, T.K., 2000, 'Guidelines for incorporating traditional folk music in the national general music curriculum of Kenya', unpublished DMus dissertation, University of Oregon.

Nketia, J.H.K., 1974, The music of Africa, Norton, New York.

Nketia, J.H.K., 1999, A guide for the preparation of primary school African music teaching manuals, UNESCO, Accra.

Norbeck, E., 1974, The anthropological study of human play, The William March Rice University, VA.

Nyota, S. \& Mapara, J., 2008, 'Shona traditional children's games and play: Songs as indigenous ways of knowing', The Journal of Pan African Studies 2(4), 189-202.

Nzewi, M., 2003, 'Acquiring knowledge of the musical arts in traditional society', in A. Herbst, M. Nzewi \& K. Agawu (eds.), Musical arts in Africa: Theory, practice and education, pp. 13-37, University of South Africa, Pretoria.

Odora Hoppers, C., 2000, 'African voices in education: Retrieving the past, engaging the present, and shaping the future', in P. Higgs, N.C.G. Vakalisa, T.V. Mda \& N.T. Assie-Lumumba (eds.), African voices in education, pp. 1-11. Juta, Lansdowne.

Okafor, R.C. \& Ng'andu, J., 2005, 'Musical storytelling', in A. Herbst, M. Nzewi \& K. Agawu (eds.), Emerging solutions for musical arts education in Africa, pp. 179-214, African Minds, Cape Town.
Okonkwo, R., 1998, 'Cultural nationalism in the colonial period', in African philosophy: An anthology, pp. 255-259, Blackwell Publishing, Oxford.

Omolewa, M., 2007, 'Traditional African modes of education: Their relevance in the modern world', International Review of Education 53(5-6), 593-612. http:// dx.doi.org/10.1007/s11159-007-9060-1

Omolo-Ongati, R.A., 2005, 'Game songs and folktales songs as teaching resources in musical arts education of a Luo Child', in A. Herbst (ed.), Emerging solutions for musical arts education in Africa, pp. 235-249, African Minds, Cape Town.

Pai, S.J., 2009, 'Discovering musical characteristics of children's songs from various parts of the world', Master of Arts, The University of British Columbia, Vancouver, viewed n.d. from https://circle.ubc.ca/bitstream/2429/.../1/ubc_2009_spring_pai_shihyu.pdf

Philpott, C., 2001, 'The body and musical literacy', in C. Philpott \& C. Plummeridge (eds.), Issues in music teaching, pp. 79-91, Routledge, London.

Rogers, S. \& Evans, J., 2008, Inside role-play in early childhood education: Researching young children's perspectives, Routledge, New York.

Schurink, W. \& Fouché, C.B., 2011, 'Qualitative research designs', in A.S De Vos, H. Strydom, C.B. Fouché \& H. Delport (eds.), Research at grass roots, 4th edn., pp. 307-327, Van Schaik, Pretoria.

Scrimsher, S. \& Tudge, J., 2010, 'The teaching/learning relationship in the first years of school: Some revolutionary implications of Vygotskya's theory', Early Education \& Development 14(3), 293-312. http://dx.doi.org/10.1207/s15566935eed1403_3

Seidlhofer, B., 2005, 'English as a Lingua Franca', ELT Journal 59(4), 339-341. http:// dx.doi.org/10.1093/elt/cci064

Stevens, R. \& Akrofi, E., 2010, 'South Africa: Indigenous roots, cultural imposition and an uncertain future', in G. Cox \& R. Stevens (eds.), The origins and foundations of music education: Cross-cultural historical studies of music in compulsory schooling, pp. 221-235, Continuum, London.

Tracey, A., 1980, 'White response to African music', paper presented at the Symposium on Ethnomusicology, Rhodes University, Grahamstown.

Vreden, M.V, 2016, 'Maestro for a moment: A conceptual framework for music integration in Grade $R^{\prime}$, South African Journal of Childhood Education 6(1), 1-10. http://dx.doi.org/10.4102/sajce.v6i1.373

Zambia, 1996, Educating our future, Zambia Educational Publishing House, Lusaka.

Zambia, 2012, Zambia education curriculum framework, Curriculum Development Centre, Lusaka. 